\title{
Research on the Development of E-commerce Model of Agricultural Products
}

\author{
Yaping Huo and Huiping $\mathrm{Mu}$ \\ Management Engineering Department, ZhengZhou University, ZhengZhou, China
}

\begin{abstract}
In recent years, electronic commerce of agricultural products has developed rapidly.In the development process of electronic commerce of agricultural products,many classic cases and business models have emerged.Such as tootoo industrial commune model(product drive type), Original life model(marketing driven type),Suichang model(service platform type).The author analyzes and compares each model from 7 aspects,and summarizes their differences and links.Finally, The author puts forward suggestions on the development of electronic commerce of agricultural products in china.
\end{abstract}

\section{Introduction}

\subsection{Background and significance of the study}

Electronic commerce of agricultural products is a new way of selling and circulating agricultural products.In recent years ,electronic commerce of agricultural products has developed rapidly.According to Alibaba agricultural ecommerce white paper (2015),Sales of agricultural products reached 69.55 billion yuan on Ali platform in 2015.The number of sellers of agricultural products was 762,100 in 2014, and The number of sellers more than 900,000 in 2015 , which accounted for $97.73 \%$ of retail platforms.[1]

In 2005, Fresh electricity business started to develop.Along with the development of e-commerce of agricultural products,there have been a variety of classic cases of e-commerce of agricultural products.Such as Futian network,tootoo industrial commune, Original life,sfbest. Agricultural electricity suppliers is becoming more and more,and some electricity suppliers have begun to profit.Because farmers are not familiar with e-commerce, and the business of electronic business enterprise involves purchase, processing, sale, logistics and platform construction, operation and maintenance and other links, Agricultural Electronic Commerce face the following problems:(1) the slow development of electronic commerce in traditional enterprises.(2) the farmers only conduct online sales, ignoring the quality of agricultural products.(3) the government does not know how to support the development of e - commerce.

Through reading the references at home and abroad, the author finds out a phenomenon. There are many literatures about electronic commerce, but there is little research on the e-commerce of agricultural products.The reasearch on the classic cases of electronic commerce of agricultural products has have great significance:First, with the popularity of the Internet and the improvement of rural network coverage, farmers will be able to open the shop at home. However, due to the lack of knowledge of agricultural electricity suppliers, farmers do not know how to operate a good shop.So there are many shops, but the number of profitable shops is not much.How to help farmers to operate the shop is a problem that needs to be solved.Second,people need more and more kinds of agricultural products, and people require more and more high quality of food,so government regulation of agricultural products is becoming more and more difficult.How to reduce the difficulty of government regulation is an urgent need to be resolved. Third, the development of electronic commerce of agricultural products can increase farmers' income and create more jobs.

\subsection{The research status at home and abroad}

The case study of electronic commerce of agricultural products is relatively small at present.Zhao Ping, Luo Yi (2011) analyzed the service orientation, brand building and so on, and put forward five enlightenment to our country to carry out electronic commerce of agricultural products:First,the focus of the development of electronic commerce of agricultural products is to improve farmers' income and service consumers. Second,The situation of electronic commerce of agricultural products can be varied, But in the end, the whole process should be formed in the closed loop operation, which includes production, procurement to the transaction, distribution and other links.finally electronic commerce of agricultural products realizes the docking of the production, supply and sale of agricultural products.Third,the government should pay attention to regional development.Fourth,in order to carry out electronic commerce of agricultural products, Online retailers should first occupy a certain market, and then seek further development.Fifth, The integration of the supply chain should pay attention to the information sharing of each 
node.[2]Luo Yi (2012) analyzed the development of agricultural products e-commerce enterprises.He made five suggestions to the government.First, the government should affirm the prospect of the development of electronic commerce of agricultural products.Second, according to the actual situation, the government should selectively support the development of the electronic commerce enterprises of agricultural products.Third, the government should pay attention to the way to support and the key points of support.Fourth, the government should make a standard. Fifth, the government should strengthen its own management of the quality of agricultural products, and promote the formation of high quality and favorable price environment.[3]

\subsection{Research ideas}

In view of the current problems of e-commerce of agricultural products in China,The author analyzed the classic case of e-commerce of agricultural products, and sorted out the different patterns, then summarized the differences between the models and links.Finally, some suggestions were put forward from three different perspectives: farmer (or rural cooperatives), e-commerce enterprises and government.

\section{Cases description}

\subsection{Tootoo industrial commune}

Tootoo industrial commune officially launched,which is $\mathrm{B} 2 \mathrm{C}$ online store and specializes in providing fresh products.In 2012 , Tootoo industrial commune operating income increased by $181 \%$ over 2012 , reaching $23,112,000$ yuan, and gross profit is $4,749,000$ yuan.[4]

Tootoo industrial commune controls the upstream side.Tootoo farm covers an area of 1050 acres in the Pinggu area of Beijing.From the choice of seed, fertilization, pest control, to the harvest of agricultural products, packaging,It is strictly in accordance with the standard implementation.It guarantees the quality of organic food in the whole production process.Ninetowns Group is the parent company of Tootoo industrial commune,which is a software company and provides inspection system software services to domestic export food enterprises.So Tootoo industrial commune can find outstanding foreign trade food export enterprises as their suppliers,and it can guarantee the distribution of all orders and master the price of the initiative.

Tootoo industrial commune establishes its own cold chain distribution.It has insisted on building its own logistics system from the beginning. The company set up a 4,000 square meters of logistics center,which integrates cold storage, freezing and processing into one body.It purchased a refrigerated truck.By using full cold chain distribution model, it achieves the goal of "fresh distribution everyday".

Tootoo industrial commune occupies the channel.In addition to their own Web site,It also opened its own shop on third-party platforms,such as Tmall, Jingdong, Kuba and so on.In addition to the initial market in Beijing,It still developed the market in Shanghai and Shenzhen and other first-tier cities.At first it took several categories to test and took the virtual inventory method to carry on the remote controll, and finally provide all products.

\subsection{Originally living network}

Originally living network caused a lot of attention at the beginning.On the one hand,It's Southern Newspaper that founded it,and It invested hundreds of millions of funds for warehousing and logistics distribution team. This is rare in the fresh electricity suppliers. [5]

Originally living network buys products in place of origin. Their buyers need to determine the topic through the opening of the topic,then began to go deep into the local area, and inspect the local specialty, and began sourcing products.Only choosing the best food in the season is the principle of buyers.

Originally living network integrated supply chain.In the process of purchasing of litchi, It made a comprehensive supply chain integration about Gaozhou litchi.Consumers believe there is no difference between Gaozhou litchi with good quality and Hainan litchi,so general manager Hu Haiqing proposed the local government to create a concept of origin which is similar to the "Gannan navel orange".

Originally living network promotes marketing through the media.Buyers should not only choose the high quality products, but also to write paperwork.Excellent marketing capabilities brought more partners.

\subsection{Suichang model}

Suichang model is considered to be China's first service platform driven agricultural e-commerce model.It is driven by a localized e-commerce integrated service provider.It drives the ecological development of county e-commerce and promotes local traditional industries. [6]

E-businessmen develop together.Suichang online shop association played a key role in the formation of ebusinessmen cluster model.Association is not only the rural e-commerce public service platform, but also the company,and it is self-financing.[7] 
Sales of agricultural products is its characteristics. Online trading of agricultural products include nuts and snacks, dried goods, tea, fresh fruits and vegetables. Now fresh fruits and vegetables gradually become the main products in the transaction.Local cooperatives have high-quality product resources, but lack of e-commerce experience and talent.On the agricultural products distribution platform set up by the association, the electricity businessmen achieve a lower cost of network sales, and it speeds up the transformation process of traditional enterprises.

Government support and investment in e-commerce.First, the government has built infrastructure,such as transportation, broadband and industrial parks.Second, the government has formulated policies.Beginning in 2011, each year 200 million in financial assistance is used for Suichang e-commerce development.

\section{Analysis on the e-business model of agricultural products}

\subsection{Tootoo industrial commune model (product-driven type)}

Tootoo industrial commune has its own farm. The author browsed its website,and found some information about the farm. The details are shown in table 1:

\subsection{Original life model(marketing driven type)}

The author browsed its website, and found some marketing activities. The details are shown in table 2:

\subsection{Suichang model(service platform type)}

The company provides members with the following services,As shown in Table 3.

\subsection{Comparison of the models}

According to the above description, The author compared the seven aspects of each model.The comparison results are shown in Table 4:

Table 1. The specific circumstances of the farm

\begin{tabular}{|c|c|}
\hline Item & Detailed content \\
\hline Farm profile & $\begin{array}{c}\text { The farm is located in Ma Changying Town, Pinggu District, northeast of Beijing, and covers an } \\
\text { area of } 1050 \text { mu.There are forest cultivation, organic cultivation, tourism and leisure, farming } \\
\text { experience, science education, catering, etc. }\end{array}$ \\
\hline $\begin{array}{l}\text { Organic } \\
\text { farming }\end{array}$ & $\begin{array}{l}\text { From the purchase of seeds, seedlings, pest control to cultivation techniques, there are strict } \\
\text { operation and control system.Farm refused to use pesticides and fertilizers, followed the natural } \\
\text { growth of plants. }\end{array}$ \\
\hline $\begin{array}{l}\text { Organic } \\
\text { farming }\end{array}$ & $\begin{array}{l}\text { From the purchase of seeds, seedlings, pest control to cultivation techniques, there are strict } \\
\text { operation and control system.Farm refused to use pesticides and fertilizers, followed the natural } \\
\text { growth of plants. }\end{array}$ \\
\hline $\begin{array}{l}\text { free- } \\
\text { rangeunder } \\
\text { the woods }\end{array}$ & $\begin{array}{l}\text { Poultry free to find food without the addition of any promoting agent. So livestock and poultry } \\
\text { growth is relatively slow, resistance, immunity is very strong, no drug residues.here are standard } \\
\text { operation and control system throughout }\end{array}$ \\
\hline $\begin{array}{c}\text { Organic } \\
\text { certification }\end{array}$ & $\begin{array}{l}\text { 2009: through the domestic organic standards and the EU organic standard double certification; } \\
\text { 2012: access to the state inspection and Quarantine Bureau for the record for the quality of } \\
\text { vegetable base in Hong kong; } \\
\text { 2013: won the title of excellent production base of Beijing food basket standardized the Beijing } \\
\text { Municipal Council issued }\end{array}$ \\
\hline $\begin{array}{l}\text { Tracing } \\
\text { system }\end{array}$ & $\begin{array}{l}\text { It consists of an external and internal traceability system.Consumers to buy products can get a } \\
\text { technology center certification card, scratch card can get a set of organic code, and then through } \\
\text { the internal traceability system can get the product specific information. Thus ensuring the full } \\
\text { traceability of the product. }\end{array}$ \\
\hline $\begin{array}{c}\text { Activity } \\
\text { recruitment }\end{array}$ & Recruiting at WeChat.Experiencer can get free vegetables by providing screenshots to the staff. \\
\hline Amusement & Organic farmer's tour,Family activities,Fun games,Health food,Organic market \\
\hline
\end{tabular}




\begin{tabular}{|c|c|}
\hline $\begin{array}{c}\text { Landlord } \\
\text { plan }\end{array}$ & $\begin{array}{c}\text { Experiencer spend money to contract a piece of land on the organic farm. Tootoo industrial } \\
\text { commune is responsible for planting, fertilizing, weeding, pest and disease prevention, harvesting } \\
\text { etc.When the crops are ripe, experiencer can get a part of the organic produce. }\end{array}$ \\
\hline Live farm & $\begin{array}{c}\text { Through the entire process monitoring and intelligent instrument long-distance observation and } \\
\text { control terminal,Connecting the computer to observe the dynamics in the field. To understand the } \\
\text { control of environmental data, environmental factors, etc. So that consumers really worry about } \\
\text { food products. }\end{array}$ \\
\hline
\end{tabular}

Table 2. Marketing activities of originally life network

\begin{tabular}{|c|c|}
\hline Item & Detailed content \\
\hline $\begin{array}{c}\text { Going home for } \\
\text { dinner }\end{array}$ & $\begin{array}{c}\text { Each theme activity will have dishes and recipes which matches the theme, and there are } \\
\text { corresponding ingredients for consumers to buy. }\end{array}$ \\
\hline $\begin{array}{c}\text { Solar terms of } \\
\text { food }\end{array}$ & $\begin{array}{c}\text { They put the list of dishes corresponding to the Chinese traditional 21 solar terms out,and } \\
\text { consumers can choose and learn the solar terms of health recipes and the corresponding } \\
\text { ingredients. }\end{array}$ \\
\hline $\begin{array}{c}\text { the kitchen of } \\
\text { Original life }\end{array}$ & $\begin{array}{c}\text { The kitchen of Original life is a western restaurant with reservation service.It is mainly } \\
\text { engaged in Italian, French and Japanese cuisine. Its ingredients are from the original life. }\end{array}$ \\
\hline
\end{tabular}

Table 3 .Services for Members

\begin{tabular}{|c|c|}
\hline Item & Detailed content \\
\hline Shop training & providing online shop training for businesses, students start their own businesses, internships, \\
etc.
\end{tabular}

Table 4. The difference and connection between the models

\begin{tabular}{|c|c|c|c|}
\hline Item & $\begin{array}{c}\text { Tootoo industrial } \\
\text { commune }\end{array}$ & Original life & Suichang model \\
\hline $\begin{array}{c}\text { Whether it has its own } \\
\text { farm(Or whether the } \\
\text { product from its own } \\
\text { production) }\end{array}$ & Yes & Yo & Yes \\
\hline $\begin{array}{c}\text { Whether there are } \\
\text { overseas suppliers }\end{array}$ & Yes & Yes \\
\hline $\begin{array}{c}\text { Whether it has its own } \\
\text { logistics system }\end{array}$ & Yes & Yes & No \\
\hline $\begin{array}{c}\text { Whether there is a } \\
\text { professional food } \\
\text { quality testing standards } \\
\text { and institutions }\end{array}$ & Yes & Yes & No \\
\hline $\begin{array}{c}\text { Whether relying on } \\
\text { third-party logistics }\end{array}$ & No & No & Yes \\
\hline $\begin{array}{c}\text { Whether it is operated } \\
\text { by a specialized } \\
\text { company or association }\end{array}$ & No & No & Yes \\
\hline $\begin{array}{c}\text { Whether it has access to } \\
\text { government policy or } \\
\text { financial support }\end{array}$ & Yes & Yes \\
\hline
\end{tabular}




\section{Suggestions on the development of e-commerce of agricultural products in China}

\subsection{Recommendations to farmers (or agricultural cooperatives)}

The peasant household should return to the land and give the shop to the specialized agency operation company.Farmers can not only participate in the basic free training, but also can entrust a professional e-commerce company operating shop.At present, there are many companies to undertake such a service.In this way, farmers can focus on the cultivation of agricultural products, after all, the quality of products is one of the key factors to improve sales.

Farmers should be rational use of chemical fertilizers, pesticides, and plant agricultural products in strict accordance with the quality and safety standards of agricultural products. Now people hope that the quality and safety of agricultural products is getting higher and higher,at the same time,people are becoming less sensitive to price.So farmers must comply with a series of standards in the process of the cultivation of agricultural products.

Farming should be arranged reasonably according to market information. On the one hand,Agricultural products sales channels have not been expanded,On the other hand,farmers lack of market information,Product supply exceeds demand.

\subsection{Recommendations for e-commerce companies}

E-commerce companies should strictly control the quality, and establish a set of agricultural products quality and safety system.Producers of agricultural products do not have or lack the technical and financial resources to develop a safety system,so e-commerce companies need to develop a security system.

If own logistics strength is not strong, do a good job within a small range.E-commerce enterprises should initially set the target market within a reasonable range,and do a good job within a small range,then slowly expand market.Tootoo industrial commune has its own logistics and distribution system.Its main target market is Beijing,so it not only reduces the damage rate of the product in transit,but also control the logistics costs of the downstream supply chain.

E-commerce companies should establish a customer relationship management system to improve consumer participation. The two main components of customer relationship management system are customer value and customer satisfaction.An important concept of customer value is the value of customer delivery, which refers to the difference between total customer value and total customer cost. The significance of maximizing the value of the transfer is that the customer will buy a product that provides the highest value of the transfer.Customer satisfaction refers to the consumer's sense of pleasure or disappointment.Consumers to participate in the company's daily activities.It not only increases their value of customer delivery and satisfaction, but also increases consumer loyalty.

\subsection{Recommendations to the Government}

In addition to supporting e-commerce of agricultural products in terms of policy and funding,government should also increase investment in infrastructure construction. Now the government has provided a healthy environment for the development of agricultural products. The government should increase the road traffic, broadband coverage and other aspects of investment,especially in remote areas.Governments increase investment in infrastructure,on the one hand,it is conducive to e-commerce business day-to-day business activities, on the other hand, it is conducive to cultivating the local people's online shopping habits,increasing sales and potential customers for e-commerce enterprises.

The government should guide farmers to cooperate with large-scale e-commerce platform.If there was a region with a variety of specialty products, the Government could cooperate with the relatively large electronic business platform for example, Taobao, Jingdong, No. 1 shop, etc.,then promote local specialties.

The government should do a good job on the quality and safety of agricultural products supervision.E-commerce companies establish a set of agricultural products quality and safety system.Farmers (or agricultural cooperatives) are strictly in accordance with the standards. The government regulates the quality of agricultural products."Three-pronged approach" can really guarantee the safety of agricultural products and consumer health.

\section{References}

1. Ali Research Institute.Ali agricultural e-commerce development white paper. 12(4), 2-4, 2015.

2. Zhao Ping, Luo Yi.Case Study and Enlightenment on the development of agricultural products e-commerce-taking Food Steward" and Freshdirect as examples.Business Economics andManagement, 19-23, 2011(07).

3. Luo Yi.Some Thoughts on the Development of e-commerce of Agricultural Products in China-Study on multiple cases, 110-116, 2012(09). 
4. Cui Jing.Tootoo industrial commune:the control of whole supply chain.China 's Economy and Informa-tization, 5657, 2013(14).

5. Zhi Ying.Those things about originally life network and chu orange-Interview with assistant to the President of Originally life network.China Advertising, 85-87, 2014(08).

6. Wu Wenmi.The way of Suichang mode of letting the agricultural products business platform landing. Innovation technology, 48-49, 2014(07).

7. Ali Research Institute.research on Suichang model. (30)10, 2013. 